Abant Tıp Dergisi

Abant Medical Journal

Araştırma Makalesi / Cilt 10 Sayı 1 Yıl 2021

Research Article / Volume 10 Issue 1 Year 2021

\title{
Meme Kanserinde ADC Değerleri ile Histopatolojik Prognostik Faktörler Arasındaki îlişkinin Değerlendirilmesi
}

\author{
Relationship Between ADC Values and Histopathological Prognostic Factors in Breast Cancer \\ Esra Ümmühan MERMi YETiş ${ }^{1}$, Rahmi ÇUBUK ${ }^{1}$ iD Ahmet Midi $^{\text {iD }}$, Levent ÇELiK ${ }^{3}$ iD \\ ${ }^{1}$ Department of Radiology, Maltepe University Faculty of Medicine, Istanbul, Turkey \\ ${ }^{2}$ Department of Pathology, Bahcesehir University Faculty of Medicine, Istanbul, Turkey \\ ${ }^{3}$ Department of Radiology, Radiologica Imaging center, Istanbul, Turkey
}

Öz

GíRiş ve AMAÇ: Meme kanserinde difüzyon MR, lezyonun morfolojisi yanında, metabolik aktivitesi hakkında da bilgi vermektedir. Patolojik prognostik faktörler meme kanserli olgularda tedavi protokolünü ve sağ kalımı etkilemektedir. Bu çalışmada amacımız, meme kanserli olgularda ADC değerleri ile patolojik prognostik faktörler arasında ilişkinin değerlendirilmesidir.

YÖNTEM ve GEREÇLER: Kliniğimizde, meme kanseri tanısı ile preoperatif olarak Meme MR tetkiki yapılan 33 olgu retrospektif olarak değerlendirildi.33 olguda toplam 44 malign kitle vardı. Tüm olguların post-operatif patoloji sonuçları elde edildi. Post-op histopatolojik spesmenlerde tümor çapı, aksiler lenf nodu durumu, histolojik grade klasik prognostik faktörler olarak ve östrojen reseptör durumu, progesteron reseptör durumu moleküler prognostik faktörler olarak değerlendirilmiştir. Difüzyon meme MR özellikleri ile klasik ve moleküler histopatolojik prognostik faktörler arasındaki ilişki Mann Whitney U test, Kruskal Wallis test and Spearman korelasyon analizi kullanılarak değerlendirildi.

BULGULAR: ADC değerleri, aksiller lenf nodu tutulumu 3'den az olan olgularda (N1) aksiller lenf nodu tutulumu 4 ve/veya daha fazla olan olgulara (N2-N3) göre anlamlı düzeyde yüksek bulundu $(p=0,011 ; p=0,010 ; p<0,05)$.

TARTIŞMA ve SONUÇ: Sonuç: Düşük $A D C$ değerleri lenf nodu tutulumuyla ilişkiliydi.

Anahtar Kelimeler: Difüzyon, Meme Kanseri, Manyetik Rezonans Görüntüleme

\section{Abstract}

INTRODUCTION: To evaluate the relationship between ADC values and histopthological prognostic factors in breast cancer patients. Materials and Methods A total of 33 female breast cancer patients with preoperative breast MRI image were retrospectively evaluated. There were a total of 44 malignant masses in 33 patients.

METHODS: In postoperative evaluation of histopathological specimens, conventional prognostic factors used were the tumor diameter, axillary lymph nodes and histological grade, and the molecular prognostic factors used were estrogen and progesterone receptor expression, C-erb-B2. In diffusion MR with a b-value of $1000 \mathrm{~s} / \mathrm{mm}^{2}$ and 1500 $\mathrm{s} / \mathrm{mm}^{2}$, the relationship between apparent diffusion coefficient (ADC) and conventional and molecular histopathological prognostic factors was evaluated by using statistical methods such as Mann Whitney U test, Kruskal Wallis test and Spearman correlation analysis.

RESULTS: ADC was significiantly lower in patients with 4 and/ormore axillary lymph nodes involvement (N2-N3) compared to those with $<3$ axillary lymph nodes involvement $(p=0.011 ; p=0.010 ; p<0.05)$.

DISCUSSION and CONCLUSION: Lower ADC values are related with axillary lymph node involvement.

Keywords: Diffussion, Breast Neoplasm, Prognosis 


\section{INTRODUCTION}

Breast cancer is the most common of the cancerrelated mortality in females following the lung cancer (1). Breast cancer is a heterogeneous disease with different molecular properites, biological behaviors, clinical courses and prognosis (1-2). Breast MRI images can give information about morphologic and dynamic properties of the lesion and is usually used for the lesions that coukd not be evaluated with other imaging methods, in the evaluation of multicentricity and bilaterality, in identifying the recurrent-residual lesions and for differentiation of the lesions such as scar tissue, fat necrosis and granulation tissue $(3,4)$. The use of diffusion MRI in the breast is increasing in recent years, because it gives information about the morphology as well as microstructural charecteristics of the lesion. In malignant lesions, diffusion restriction increases and $A D C$-value decreases with the increased $b$-value.

In patients with breast canser, recent studies have been found in the literatüre on the relationship between the data obtained from preoperative breast MRI and the prognostic factors determined on postoperative evaluation of pathological specimens. These studies have particularly studied the morphological features on conventional breast MRI and have reported similar results $(1,5,6)$. Although the relationship between the diffusion breast MRI and histopathological prognostic factors was studied in recent years $(2,7-11)$. Some studies have reported that diffusion MRI images can be used to differantiate and to characterize the benign and malign breast lesions and that ADCvalues may be associated with prognostic factors (2,711).

The purpose of the present study was to evaluate the relationship between $A D C$ values and conventional (tumor size, axillary lymph node involvement, histopathological grade, multifocal disease and lenfovascular invasion) and molecular (estrogen and progesteron receptors, Cerb-B2) prognostic factors for breast cancer.

\section{METHODS}

Ethics committee approval was received from the İstanbul Kartal Dr. Lütfi Kırdar Education and Resarch Hospital Scientific Resarch and Science Board with the decision dated 05.02.2013 and numbered $8951337 / 1009 / 123$ for the study.

\section{Patients}

The consecutive patients with a diagnosis of invasive breast cancer in whom preoperative MRI had been obtained were included in the study. We excluded patients with only in situ tumors in the study. Also in order to aviod any alteration in tumor tissue due to histology or grading, the patients in whom MRI was obtained during/after neoadjuvant chemoterapy were excluded from the study. A total of 33 female breast cancer patients were included in the study. There were a total of 44 malignant masses in 33 patients.

\section{Breast MRI imaging protocol}

Breast MR imaging was performed on a 1.5T imager (Intera, Phlips Medical Systems, Best, The Netherlands) with a dedicated doublebreast fourn-channel surface coil and bilateral scans. Before the examination, a needle for intravenosu adminstration of contrast agent was placede in cubital vein. Patient was placede in a comfortable prone position. Transverse T2weighted fat a cubital vein. Patient was placed in a comfortable prone position. Transverse T2weighted fat supressed spin echo sequence (TE/TR 110/7548 ms; inversion delay SPAIR 80 ms; flip angle $90^{\circ}$; FOV $380 \times 380 \mathrm{~mm}^{2}$, acquired voxel size $1.06 \times 1.74 \times 3.0 \mathrm{~mm}^{3}$, reconstructed voxel size $0.94 \times 0 \times 94 \times 3 \times 00 \mathrm{~mm}^{3}$, total acquistion time 242s) was performed before adminstration of contrast material. DWI axial sequence:TR, $8000 \mathrm{~ms}$; TE, 82ms; 116×123 matrix; thickness, $4 \mathrm{~mm}$; FOV, $32 \mathrm{~cm}$; parallel acquistion factor: 2.0 ; and NEX, 2. DWI was acquired before dynamic sequences, with a spin-echo echoplanar imaging (EPI) sequence in the axial plane. Sensiting diffusion gradients were applied sequentially in the $x, y$ and $z$ directions, with $b$ values of 0,1000 and $1,500 \mathrm{~s} / \mathrm{mm}^{2}$. A transverse threedimensional high-resolition T1-values of 0, 1000 and $1,500 \mathrm{~s} / \mathrm{mm}^{2}$. A transverse three- 
dimensional high reslotion high-resolution T1weighted fast gradient echo fat-suppressed sequence [TE/TR 2.4/4.6 ms; inversion delay spectral presaturation attenuated by inversion recovery (SPAIR) 90ms; flip anle $10^{\circ}$; FOV $360 \times 360 \mathrm{~mm}^{2}$,acquired voxel size $0.9 \times 0.9 \times 2.5$ $\mathrm{mm}^{3}$, reconstructed voxel size $0.83 \times 0.83 \times 2.50 \mathrm{~mm}^{3}$, total acquistion time $60 \mathrm{~s}$ ] was performed before adminstration of contrast agent, followed by repeat performance of this same sequnces at $0,1,2,3,4,5$ and $6 \mathrm{~min}$. After administration of contrast agent. Postcontrast three-dimensional T1-weighted fast gradient echodynamic MR images were acquired after administration of $0.1 \mathrm{mmol} / \mathrm{kg}$ GD-DTPA (gadolinium diethylene triamine-pentaaceticacid dimeglumine). Contrast medium was injected with a 10s timing delay into the antecubital vein eith an 18-20G needle at a flow rate of $2 \mathrm{ml} / \mathrm{s}$ followed by a flush of $20 \mathrm{ml}$ of saline-solution.

\section{Image Interpretation}

Breast MRI images were evaluated by two radologist having at least 5 years of experiences in breast MR imaging. The greatest diameter of the tumor was considered for statical analysis. The place of circle $<$ ROI (region of interest) was determined by the consensus of two radiologists. A single ROI with 5-10 $\mathrm{mm}^{2}$ was manually drawn around the borders of the target lesion on the $\mathrm{b}=1,000$ and $1500 \mathrm{~s} / \mathrm{mm}^{2}$ DWI. Care was taken to avoid apparent necrotic or cystic components by referring to other MRI images [13-19]. We obtained two ADC map (b-1000 and b-1500) and we compared them.

\section{Pathological examination}

Histopathological evaluation was performed by two pathologists having at least 5 years of experience in breast histopathology. Conventional prognostic factors wew determined as tumor size, axillary lymph node involvement, multicentricity, histological and nuclear grades, and lymphovascular invasion. On the other, molecular prognostic factors were ER/PR expression, C-erb-B2.
All areas of the preperation were evaluated in the tumor cell for ER and PR, expression. Only the stained areas limited to the nuclei are considered as positiveç The intense-, normal-, and weak stained cells were multiplied by 3,2 and 1 respectively to calculate a total score with a maximum of 300 points. Those with a score of $<30$ were considered as negative.

Characteristic membranous (Chicken-Wire) staining was considered as positive for C-erb-B2. The cells with no staining or weak stainnig in $<10 \%$ of the cells were scored as $0=$ negative, those with weak staining in $>10 \%$ celss were $1+$ (negative), those with weak-moderate staining in $>10 \%$ cells were $2+$ (unclear), those with moderate-intense staining in $<30 \%$ cells were $2+$ (unclear), and those with moderate-intense staining in $>30 \%$ cells were $3+$ (strongly positive).

Estrogen and progesterone receptors were determined as positive or negative, and C-erb-B2 protein (Her-2/neu) was determined as negative, unclear or strongly positive.

Hsitological grade was determined by using modified Bloom-Richardson-Elston system which includes the nuclear polymorphism, tubule formation and mitosis parameters. Each parameter was scored from 1 to 3 obtain a total score.

Tubule formation was scored as atubulus formation of $>75 \%(=1), 10-75 \%(=2)$ or $<10 \%(=3)$.

Nucleus size was scored as follows: $1=$ equal to the norml ductus epithelium, 2=medium-sized, and $3=$ large nucleus.

Mitosis was scored on 10 bba (X400 magnificiation, $\left.0.186 \mathrm{~mm}^{2}: 2 / 3\right)$ as a mitosis count of $0-7(=1), 8-14(=2)$ or $>14(=3)$.

Nuclear grade was determined according to modified Black system as follows: for nucleus diameter, 1=small, 2=medium and 3=large; for nucleus shape, 1=regular and 2=irregular; for pleomorphisim, 1=low, 2=medium and 3=high; for nuclues, 1=not distinguished, 2=distinguished a $3=$ clear. Nuclear grade was grade I for a total 
score of 4-6, grade II for 7-8 and grade III for 911.

\section{Statistical analysis}

Statistical analysis was performed by using NCSS (Number Cruncher Statistical System) 2007\&PASS (Power Analysis and Sample Size) 2008 Statistical Software (Utah, USA). In addition to the descriptive statistics (mean, standard deviation, median, frequency and ratio), Mann Whitney $U$ test was used fort he two -group comparison of quantitative parametres with no normal distrubition. Fort he comparasion of three or more groups with no normal distrubition, Kruskal Wallis test was used, followed by Mann Whitney $U$ test to determine the group responsible from the difference. Spearman correlation analysis was used to evaulate the association between the parameters. Statistical significance set at $p<0.01$ and $p<0.05$.

\section{RESULTS}

A total of 33 female breast cancer patients who had a preoperative breast MRI image were included in the study. Study patients aged 37-76 years with a mean age of 53 years. There were a total of 44 malignant masses in 33 patients.

\section{Histologic Analysis}

The pathology report was invasive ductal carcinoma in 40 patients (91\%), invasive lobular carcinoma in $3(6.8 \%)$ and ductal carcinoma in situ with an invasive component in $1(2.2 \%)$.

Tumor size ranged from 4 to $50 \mathrm{~mm}$ with a mean size of $20.00 \pm 10.94 \mathrm{~mm}$. Tumor size was $<2 \mathrm{~cm}$ in $52.3 \%$ of the patients $(n=23)$ and $2-5 \mathrm{~cm}$ in $47.7 \%(n=21)$.

Prognostic factors are summarized in Table 1. As a histological grade, there were 7 patients $(15.9 \%)$ with grade $1,13(29.5 \%)$ with grade 2 , and 24(54.6\%)with grade 3 lesions.

In 23of the 44 lesion (52.3\%), one or more lymph node involvement was found at histopsthologic examination. Of the cases, $47.7 \%(n=21)$ had no axillary lymph node, $22.7 \%(n=10)$ had $1-3,20.5 \%$ $(n=9)$ had $4-9$ and $9.1 \%(n=4)$ had more than 9 axillary lymph nodes. Lymph node involvement is summarized in Table 1.

In outr series, $88.6 \%$ of the tumors were (39/44) ER-positive and 68.2\% (30/44) were PR-positive. Thirty-two lesions showed negative $(0,1+)$ cerbB-2 protein findings, and 12 patients showed positive findings $(2+, 3+)$. The median percentage of K6-67 expression was $14.0 \%$.

\section{ADC Value Analysis}

The mean ADC-1000 value of all malignant lesions was $0.96 \times 10^{-3} \mathrm{~mm}^{2} / \mathrm{s}$ (range 0.58 $1.90 \times 10^{-3} \mathrm{~mm}^{2} / \mathrm{s}$, SD $\left.0.21 \times 10^{-3} \mathrm{~mm}^{2} / \mathrm{s}\right)$. The mean ADC-1500 value of all malignant lesions was $0.80 \times 10^{-3} \mathrm{~mm}^{2} / \mathrm{s}$ (range $0.51-1.60 \times 10^{-3} \mathrm{~mm}^{2} / \mathrm{s}$, SD $0.18 \times 10^{-3} \mathrm{~mm}^{2} / \mathrm{s}$ ) (Figs.1,2).

There was no significiant correlation between the $A D C$ value and conventional prognostic factors of age, tumor size and histologic/nuclear grades. Relation between ADC values and Prognostic Factors are summarized in Table 1. However, there was a statistical difference between axillary lymph node involvement and $A D C 1000$ and $A D C$ 1500 values (ADC $1000 p=0.017 ; p<0.05 ; A D C$ $1500 p=0.019 ; p<0.05)$. Namely, according to the two-group comparisons, there was no significiant difference in ADC -1000 and ADC-1500 values between patients with no axillary lymph node involvement compared to those with 1-3 lymph nodes involvement $(p<0.05)$. Although ADC-1000 value in patients with no axillary lymph node involvement was higher compared to those with 4-9 or >9 axillary lymph node involvement, it did not reach statistical significance (ADC 1000 $p=0.055 ; p=0.053 ; p>0.05 ; A D C 1500 p=0.063$; $p=0.075 ; p>0.05) . \quad A D C-1000$ and ADC-1500 values in patients with 1-3 axillary lymph node involvement was significiantly higher compared to those with 4-9 or $>9$ axillary involvements (ADC $1000 p=0.011 ; p=0.010 ; p<0.05 ;$ ADC 1500 $p=0.014 ; p=0.016 ; p<0.05)$. There was no significiant difference in ADC-1000 and ADC-1500 values between patients with 4-9 axillary involvement and those with $>9$ axillary involvements $(p>0.05)$. 
There was no significant correlation between the $A D C$ value and molecular prognostic factors, including ER, PR, c-erbB-2.

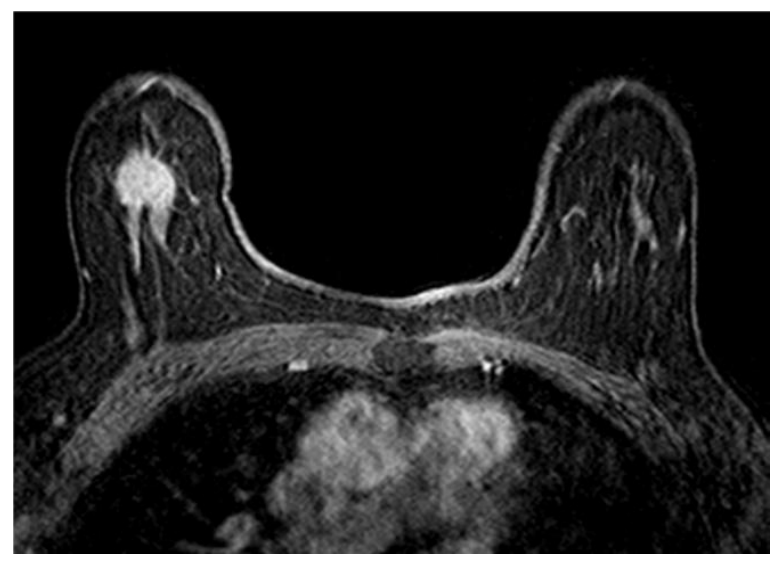

Fig. 1a

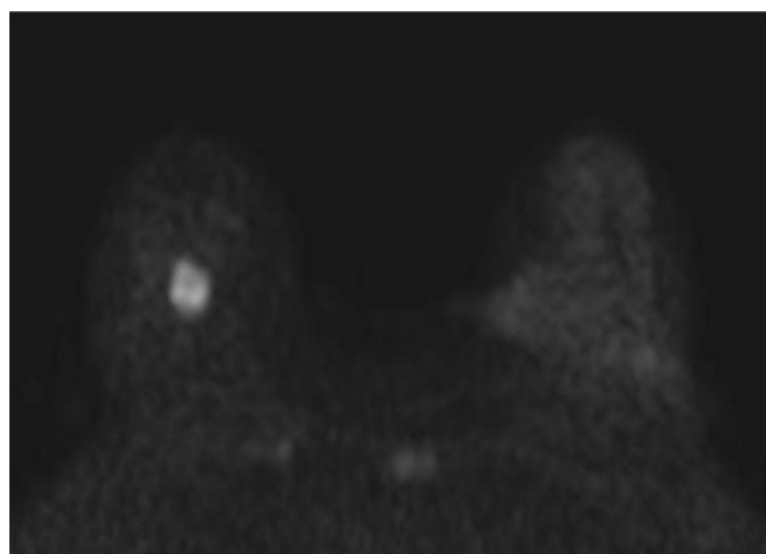

Fig. $1 b$

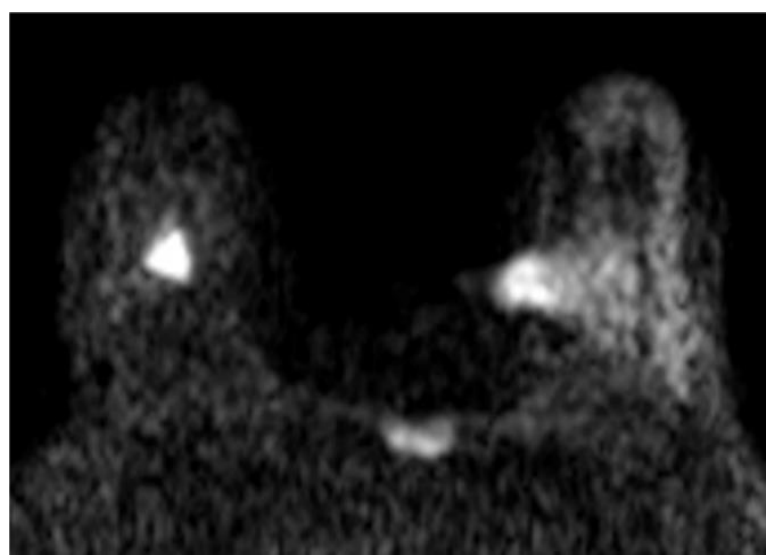

Fig. 1c

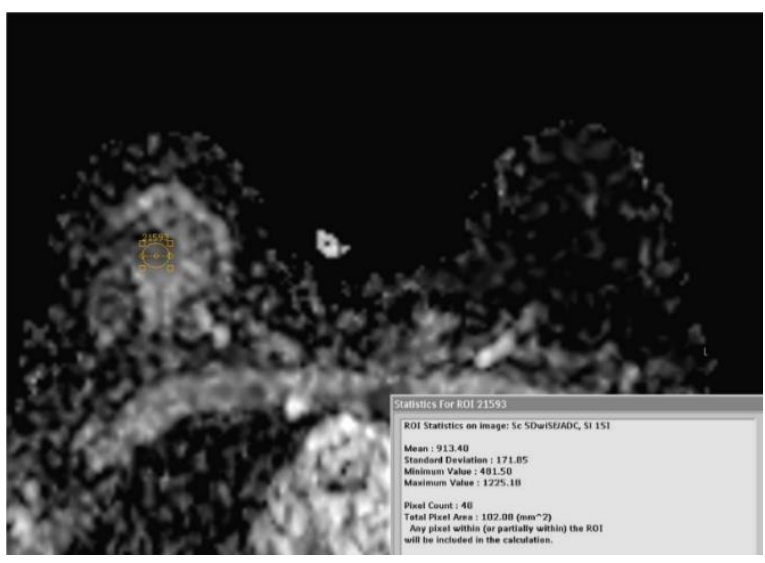

Fig. 1d

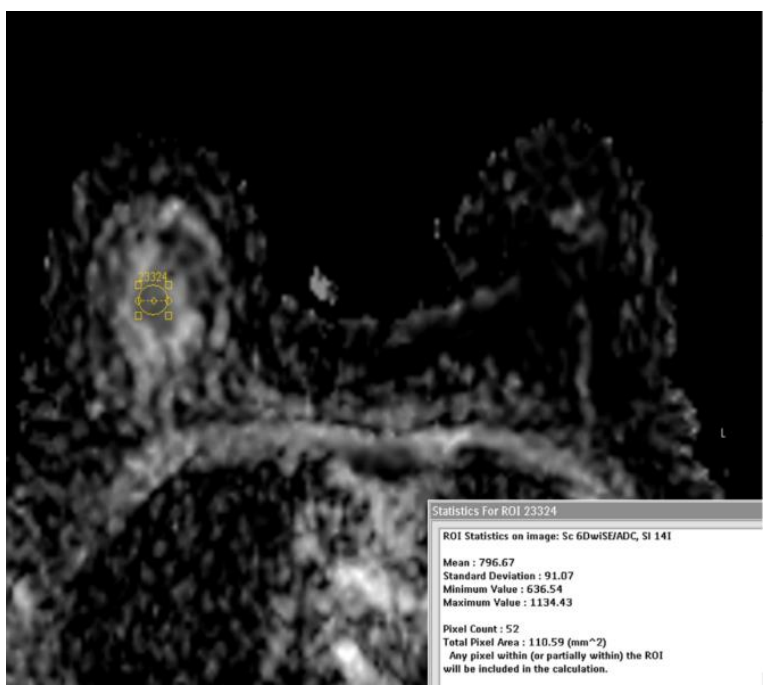

Fig. 1e

Figure 1. A 50-year-old woman with breast cancer, diagnosed as invasive ductal carcinoma, histological grade 2, ER (-), PR (+), C Erb B2 3 (+). T1 weighted axial contrast enhanced images (a) shows mass with spiculated margins in the right breast. High signal intensity was detected in the right breast on b1000 and b1500 DWI (b, c). The ADC value was found to be $0.91 \times 10^{-3} \mathrm{~mm}^{2} / \mathrm{s}$ on $1000 A D C$ map (d), $0.79 \times 10^{-3} \mathrm{~mm}^{2} / \mathrm{s}^{2}$ on $1500 A D C$ map (e). 


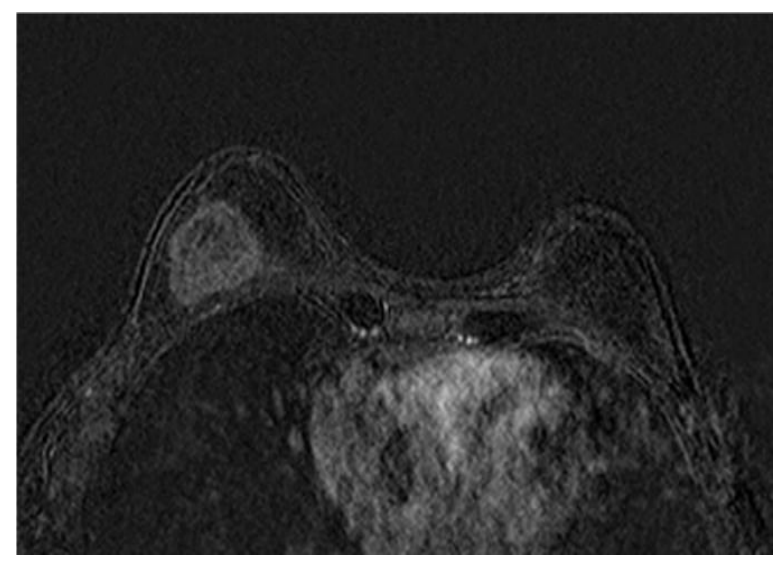

Fig. 2a

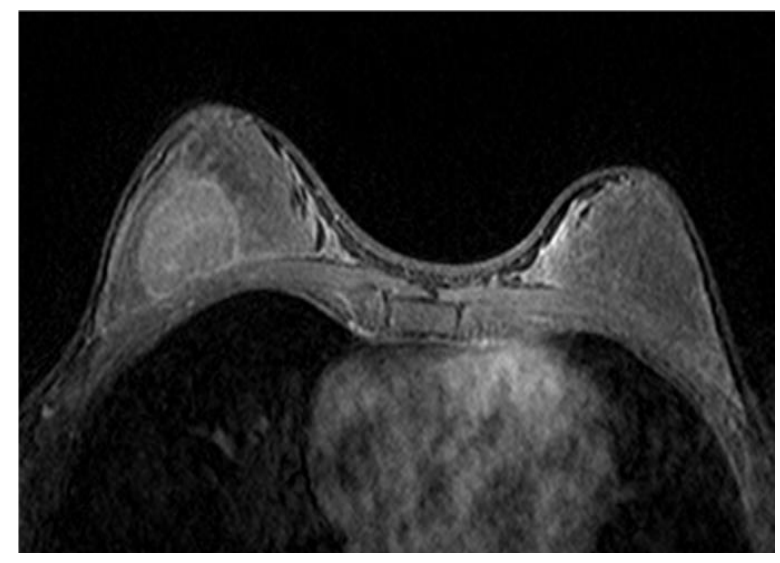

Fig. $2 b$

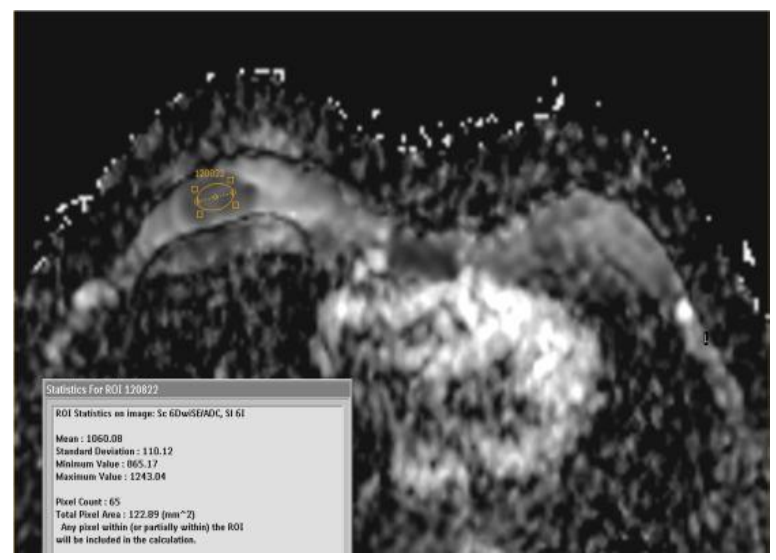

Fig. 2c

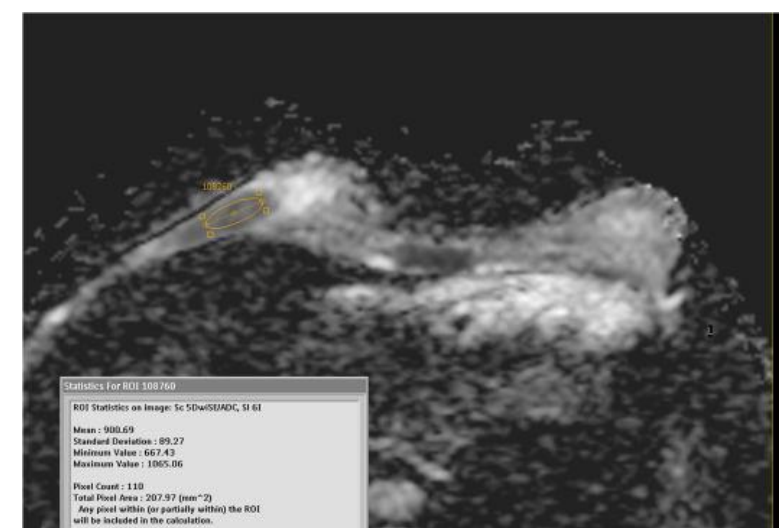

Fig. 2d

Figure 2: A 25-year-old woman with breast cancer diagnosed as invasive ductal carcinoma, histological grade 2, ER / PR $(+)$, C Erb B2. T1 weighted axial contrast enhanced and substraction (3-1) images (a, b) shows mass in the right breast. The $A D C$ value was found to be $1 \times 10^{-3} \mathrm{~mm}^{2} / \mathrm{s}$ on b1000 ADC map (c), $0.9 \times 10^{-3} \mathrm{~mm}^{2} / \mathrm{s}$ on b1500ADC map (d).

\section{DISCUSSION}

Breast cancer is a heterogenous disease chracterized by varying molecular features, biological behavior, clinical course and prognosis (1-2). Therefore, it is important to identify the concentional and molecular prognostic factors in these patients in order to determine the appropriatie therapy to increase the survival (1920). There is evidence that the progression of malignant tumours does not depend exclusevely on the cancer cells; it is also influenced by the tumour microenvironment. The tumour microenvironment is a complex system that includes tumour cells, stromal cells (such as adipocytes, fibroblasts, endothelial cells, and infiltrating immune cells), and extracellular matrix. Diffusion MR imaging has been shown to have potential in the detection and characterization of breast malignancies, based on its ability to characterize tissue microstructures $(3,4,21,22)$. Microscopic movement is influced by the molecular diffusion of the water and microcirculation of blood $(23,28)$. On the other hand, diffusion of the water is influenced by cellularity, viscosity, intracelluler and extracellular membrane permeability, active transportation, flow and structural arrangement $(23,29,30)$. ADC is a measurable value and many previous studies have showed marked diffusion 
restriction and lower $A D C$ values in malignant lesions compared to benign lesions (24,25,28,29,31-35). Restricted diffusion and thus lower $A D C$ values are due to hing cellularity in cancer tissue, large-nuclei numerous macromolecular protein content and narrowed extracellular distance $(27,31)$.

Many previous studies have showed a significiant association between morphological and kinetic properties of the mass lesions on conventional breast MRI and several poor prognostic factors in breast cancer (1,6,36-38). More recent studies have reported that $A D C$ value measured by Diffusion breast MROI is effectivein identifying the cancer tisue and the mensturation-related changes in normal breast parenchyme (23). Malignant tumors Show lower ADC values compared to benign lesions $(23,29,39)$. In these studies, authors have also investigated the association between $A D C$ value of the cancer tissue and prognostic factors for breast cancer. However, there are conflicting results in the literatüre about the association between ADC value on diffusion MRI and prognostic factors for breast cancer $(7,9-11,23)$.

In our study, there was no significiant correlation between the $A D C$ value and conventional prognostic factors, incuding age, tumor size and histologic/nuclear grades. Another conventional prognostic factor, the axillary lymph node involvement is the most important factors used to predict the prognosis of breast cancer (36). In our study, ADC-1000 and ADC-1500 values were found to be significantly higher in patients with 13 axillary lymph node involvement(N1) compared to those with 4-9(N2) and $>10$ (N3) axillary lymph node involvement. However, there was no significiant difference in ADC-1000 and ADC1500 values between the patients with no nodal involvement (NO) and N1 patients. Similarly, ADC-1000 and ADC-1500 values did not differ between patients with 4-9 and $>9$ axillary lymph nodes. According to the TNM staging system regardless of what is T (primary tumor), N2 and N3 patients (4 or more nodal involvement) are classified as stage 3 or more. As a result, lower $A D C$ values found in $\mathrm{N} 2$ and N3 patients compared N0 and N1 patients indicates its association with poor prognostic factors.

Similar to our results, Abdel Razek (9) and Paola Belli et al. (2) have also reported a correlation between low ADC values and positive axillary lymp nodes. On the other hand, in contrast to our results, Takashi Kamitani et al. (10) have found hinger ADC values in patients with positive axillary lymp nodes. In the study by Sung Hun Kim et al. (23), ADC values were not correlated with lymp node involvement. Thsi may be due to the fact that authors have included the subgroups of musinous and medullar cancers which are usually associated with high ADC values. It has been already reported that $A D C$ values are higher in mucinous and medullar cancer due to the inflammation associated with higher cellularity (18). There were no patients with musinous or medullar cancer in our study. We included only the patients with invasive ductal and invasive lobular carcinoma as well as in situ carcinomas with an invasive component.

In our study, there was no significiant correlation between the $A D C$ value and molecular prognostic factors, including ER, PR, c-erbB-2. Similarly, Sung Hun Kim et al. (23) have found no correlation between ADC value and ER/PR expression. On the other hand, in the srudies by Takashi Kamitani et al. (10) Laura Martincich et al. (7) and SY Choi et al. (11), ER expression was correlated with low $A D C$ values. Similar to our study, SY Choi et al. (11), Sung hun Kim et al. (23) and Takashi Kamitani et al. (10) have also reported no correlation between C-erb-B2 and ADC values. Howeveer, Laura Martincich et al. (7) reported a correlation between low $A D C$ values and negative Cerb-B2 values.

Limitations of our study the relative inadequacy in the number of patients as well as lack of astandard $b$ value for diffusion MRI, resulting in conflicting results in previous studies using different $b$ values. Moreover, size of the tumor was $<1 \mathrm{~cm}$ in 7 and $<2 \mathrm{~cm}$ in 24 out of 44 lesions. In small lesions, 3T dW MRI is more effective than 1.5T MRI in identifying a lesion. Because we used 1.5T MRI in our study, the reliability is low for 
small lesions. On the other hand, Marini et al. (29) have found that $A D C$ values are lower in patients with invasive ductal carcinoma compared to those with other cancer types and we had 3 invasive lobular carcinoma patients in our series. Thus larger and homogeneous patient series are needed for future studies.

In conclusion, $A D C$ value was found to be significiantly lower in patients with N2 and N3 disease (axillary lymph node involvement of 4 or more) compared to those with $\mathrm{N} 1$ disease (axillary lymph node involvement $<3$ ) according to TNM staging system. Despite the lacking the number of the study results of the present study suggest that low ADC value is correlated with lymph node involvement and thus with poor prognosis.

The authors would like to present their thanks to the radiology technologist Esin Gül, for her technical support.

The Authors declares that there is no conflict of interest.

Informed Consent: Written consent was obtained from the participants.

Conflict of Interest: Authors declared no conflict of interest.

Financial Disclosure: Authors declared no financial support.

\section{REFERENCES}

1. Tuncbilek N, Karakas HM, Okten OO. Dynamic Magnetic Resonance Imaging in Determining Histopathological Prognostic Factors of Invasive Breast Cancers. Eur J Radiol. 2005 Feb;53(2):199-205. doi: 10.1016/j.ejrad.2003.11.004.

2. Belli $P$, Costantini $M$, Bufi E, Giardina GG, Rinaldi $P$, Franceschini $G$ et al. Diffusion Magnetic Resonance Imaging in Breast Cancer Characterisation: Correlations Between the Apparent Diffusion Coefficient and Major Prognostic Factors. Radiol Med. 2015 Mar;120(3):26876. doi: $10.1007 / \mathrm{s} 11547-014-0442-8$.

3. M C Segel, D D Paulus, G N Hortobagyi. Advanced Primary Breast Cancer: Assessment at Mammography of Response to Induction Chemotherapy. Radiology. 1988 Oct;169(1):49-54. doi: 10.1148/radiology.169.1.3420282.
4. Kolb TM, Lichy J, Newhouse JH. Comparison of the Performance of Screening Mammography, Physical Examination, and Breast US and Evaluation of Factors That Influence Them: An Analysis of 27,825 Patient Evaluations. Radiology 2002 Oct;225(1):165-75. doi: 10.1148/radiol.2251011667.

5. Lee SH, Cho N, Kim SJ, Cha JH, Cho KS, Ko ES et al. Correlation Between High Resolution Dynamic MR Features and Prognostic Factors in Breast Cancer. Korean J Radiol. 2008 Jan-Feb;9(1):10-8. doi: 10.3348/kjr.2008.9.1.10.

6. Mussurakis S, Buckley DL, Horsman A. Dynamic MR Imaging of Invasive Breast Cancer: Correlation With Tumour Grade and Other Histological Factors. $\mathrm{Br} \mathrm{J}$ Radiol. 1997 May;70(833):446-51. doi: 10.1259/bjr.70.833.9227224.

7. Martincich L, Deantoni V, Bertotto I, Redana S, Kubatzki F, Sarotto I et al. Correlations Between DiffusionWeighted Imaging and Breast Cancer Biomarkers. Eur Radiol. 2012 Jul;22(7):1519-28. doi: 10.1007/s00330012-2403-8. Epub 2012 Mar 13.

8. Pereira FP, Martins G, Carvalhaes de Oliveira Rde V. Diffusion Magnetic Resonance Imaging of the Breast. Magn Reson Imaging Clin N Am. 2011 Feb;19(1):95110. doi: 10.1016/j.mric.2010.09.001.

9. Razek AA, Gaballa G, Denewer A, Nada N. Invasive ductal carcinoma: correlation of apparent diffusion coefficient value with pathological prognostic factors. NMR Biomed. 2010 Jul;23(6):619-23. doi: 10.1002/nbm.1503.

10. Kamitani T, Matsuo Y, Yabuuchi H, Fujita N, Nagao M, Jinnouchi $M$ et al. Correlations between apparent diffusion coefficient values and prognostic factors of breast cancer. Magn Reson Med Sci. 2013;12(3):193-9. doi: 10.2463/mrms.2012-0095. Epub 2013 Jul 12.

11. Choi SY, Chang YW, Park HJ, Kim HJ, Hong SS, Seo DY. Correlation of the apparent diffusion coefficiency values on diffusion-weighted imaging with prognostic factors for breast cancer. $\mathrm{Br} J$ Radiol. 2012 Aug;85(1016): e474-9. doi: 10.1259/bjr/79381464. Epub 2011 Nov 29.

12. Woodhams R, Matsunaga K, Kan S, Hata H, Ozaki M, Iwabuchi $\mathrm{K}$ et al. ADC mapping of benign and malignant breast tumors. Magn Reson Med Sci. 2005 Aug ;4(1):35-42. doi: 10.2463/mrms.4.35.

13. Yoshikawa MI, Ohsumi $S$, Sugata $S$, Kataoka $M$, Takashima S, Mochizuki T et al. Relation between cancer cellularity and apparent diffusion coefficient values using diffusion-weighted magnetic resonance imaging in breast cancer. Radiat Med. 2008 May;26(4):222-6. doi: 10.1007/s11604-007-0218-3. Epub 2008 May 29.

14. Guo Y, Cai YQ, Cai ZL, Gao YG, An NY, Ma L et al. Differentiation of clinically benign and malignant breast lesions using diffusion-weighted imaging.J Magn Reson Imaging. 2002 Aug;16(2):172-8. doi: 10.1002/jmri.10140.

15. Park MJ, Cha ES, Kang BJ, Ihn YK, Baik JH. The role of diffusion-weighted imaging and the apparent diffusion 
coefficient (ADC) values for breast tumors. Korean J Radiol. 2007 Sep-Oct;8(5):390-6. doi: 10.3348/kjr.2007.8.5.390.

16. Hatakenaka M, Soeda $H$, Yabuuchi $H$, Matsuo $Y$, Kamitani T, Oda $Y$ et al. Apparent diffusion coefficients of breast tumors: clinical application. Magn Reson Med Sci. 2008 May;7(1):23-9. doi: 10.2463/mrms.7.23.

17. Yabuuchi $H$, Matsuo $Y$, Okafuji $T$, Kamitani $T$, Soeda $H$, Setoguchi $T$ et al. Enhanced mass on contrastenhanced breast MR imaging: Lesion characterization using combination of dynamic contrast-enhanced and diffusion-weighted MR images. J Magn Reson Imaging. 2008 Nov;28(5):1157-65. doi: 10.1002/jmri.21570.

18. Woodhams R, Kakita S, Hata H, Iwabuchi K, Umeoka S, Mountford CE et al. Diffusion-weighted imaging of mucinous carcinoma of the breast: evaluation of apparent diffusion coefficient and signal intensity in correlation with histologic findings. AJR Am J Roentgenol. 2009 Jul;193(1):260-6. doi: 10.2214/AJR.08.1670

19. Esteva FJ, Hortobagyi GN. Prognostic molecular markers in early breast cancer. Breast Cancer Res. 2004 Mar;6(3):109-18. doi: 10.1186/bcr777. Epub 2004 Mar 11.

20. Fischer U, Kopka L, Brinck U, Korabiowska M, Schauer A, Grabbe E. Prognostic value of contrast-enhanced MR mammography in patients with breast cancer. Eur Radiol. 2014 February 1997;7(7):1002-5. doi: 10.1007/s003300050240.

21. Cody DD, Mahesh M. AAPM/RSNA physics tutorial for residents: Technologic advances in multidetector CT with a focus on cardiac imaging. Radiographics. 2007 Nov-Dec;27(6):1829-37. doi: 10.1148/rg.276075120.

22. W A Kaiser. Dynamic Spiral MR Mammography.Radiology 2000 Jun;215(3):919-20. doi: 10.1148/radiology.215.3. r00ap45919.

23. Kim SH, Cha ES, Kim HS, Kang BJ, Choi JJ, Jung JH et al. Diffusion-weighted imaging of breast cancer: correlation of the apparent diffusion coefficient value with prognostic factors.J Magn Reson Imaging. 2009 Sep;30(3):615-20. doi: 10.1002/jmri.21884.

24. Woodhams R, Matsunaga K, Iwabuchi K, Kan S, Hata H, Kuranami $M$ et al. Diffusion-weighted imaging of malignant breast tumors: the usefulness of apparent diffusion coefficient (ADC) value and ADC map for the detection of malignant breast tumors and evaluation of cancer extension. J Comput Assist Tomogr. 2005 SepOct;29(5):644-9.

doi: 10.1097/01.rct.0000171913.74086.1b.

25. Kinoshita T, Yashiro N, Ihara N, Funatu H, Fukuma E, Narita M. Diffusion-weighted half-Fourier single-shot turbo spin echo imaging in breast tumors: differentiation of invasive ductal carcinoma from fibroadenoma. J Comput Assist Tomogr. 2002 NovDec;26(6):1042-6. doi: 10.1097/00004728-20021100000033.

26. Pereira FP, Martins G, Figueiredo E, Domingues MN, Domingues RC, da Fonseca LM et al. Assessment of breast lesions with diffusion-weighted MRI: comparing the use of different $b$ values. AJR Am J Roentgenol. 2009 Oct;193(4):1030-5. doi: 10.2214/AJR.09.2522.

27. Pereira FP, Martins G, Figueiredo E, Domingues $M N$, Domingues RC, da Fonseca LM et al. Assessment of breast lesions with diffusion-weighted MRI: comparing the use of different $b$ values. AJR Am J Roentgenol. 2009 Oct;193(4):1030-5. doi: 10.2214/AJR.09.2522.

28. Costantini M, Belli P, Rinaldi P, Bufi E, Giardina G, Franceschini $G$ et al. Diffusion-weighted imaging in breast cancer: relationship between apparent diffusion coefficient and tumour aggressiveness. Clin Radiol. 2010 Dec;65(12):1005-12. doi: 10.1016/j.crad.2010.07.008. Epub 2010 Sep 24.

29. Marini C, lacconi C, Giannelli M, Cilotti A, Moretti M, Bartolozzi C. Quantitative diffusion-weighted MR imaging in the differential diagnosis of breast lesion. Eur Radiol. 2007 Oct;17(10):2646-55. doi: 10.1007/s00330-007-0621-2. Epub 2007 Mar 14.

30. Buadu LD, Murakami J, Murayama S, Hashiguchi N, Sakai S, Masuda $\mathrm{K}$ et al. Breast lesions: correlation of contrast medium enhancement patterns on MR images with histopathologic findings and tumor angiogenesis. Radiology. 1996 Sep;200(3):639-49. doi: 10.1148/radiology.200.3.8756909.

31. Guo Y, Cai YQ, Cai ZL, Gao YG, An NY, Ma L et al. Differentiation of clinically benign and malignant breast lesions using diffusion-weighted imaging. J Magn Reson Imaging. 2002 Aug;16(2):172-8. doi: 10.1002/jmri.10140.

32. Partridge $S C$, Mullins $C D$, Kurland $B F$, Allain $M D$, DeMartini WB, Eby PR et al. Apparent diffusion coefficient values for discriminating benign and malignant breast MRI lesions: effects of lesion type and size. AJR Am J Roentgenol. 2010 Jun;194(6):1664-73. doi: 10.2214/AJR.09.3534.

33. Rubesova E, Grell AS, De Maertelaer V, Metens T, Chao $\mathrm{SL}$, Lemort M. Quantitative diffusion imaging in breast cancer: a clinical prospective study. J Magn Reson Imaging. 2006 Aug;24(2):319-24. doi: 10.1002/jmri.20643.

34. Sinha S, Lucas-Quesada FA, Sinha U, DeBruhl N, Bassett LW. In vivo diffusion-weighted MRI of the breast: potential for lesion characterization. J Magn Reson Imaging. 2002 Jun;15(6):693-704. doi: 10.1002/jmri.10116.

35. Yabuuchi $H$, Matsuo $Y$, Okafuji $T$, Kamitani $T$, Soeda $H$, Setoguchi et al. Enhanced mass on contrast-enhanced breast MR imaging: Lesion characterization using combination of dynamic contrast-enhanced and diffusion-weighted MR images. J Magn Reson Imaging. 2008 Nov;28(5):1157-65. doi: 10.1002/jmri.21570.

36. Szabó BK, Aspelin $P$, Kristoffersen Wiberg $M$, Tot $T$, Boné $B$. Invasive breast cancer: correlation of dynamic MR features with prognostic factors.Eur Radiol. 2003 Nov;13(11):2425-35. doi: 10.1007/s00330-003-2000-y. Epub 2003 Jul 26.

37. Montemurro F, Martincich L, Sarotto I, Bertotto I, Ponzone R, Cellini L et al. Relationship between DCEMRI morphological and functional features and 
histopathological characteristics of breast cancer. Eur Radiol. 2007 Jun;17(6):1490-7. doi: 10.1007/s00330006-0505-x. Epub 2006 Dec 6.

38. Narisada H, Aoki T, Sasaguri T, Hashimoto H, Konishi T, Morita $\mathrm{M}$ et al. Correlation between numeric gadolinium-enhanced dynamic MRI ratios and prognostic factors and histologic type of breast carcinoma. AJR Am J Roentgenol. 2006 Aug;187(2):297306. doi: 10.2214/AJR.05.0696.

39. Iacconi C. Diffusion and perfusion of the breast. Eur J Radiol. 2010 Dec;76(3):386-90. doi: 10.1016/j.ejrad.2010.03.009. Epub 2010 Apr 21 
Tablo 1. Relation Between ADC Value and Prograstic Factors

\begin{tabular}{|c|c|c|c|c|c|}
\hline Factors & $\begin{array}{l}\text { Number of } \\
\text { Lesions (n:44) }\end{array}$ & $\begin{array}{c}\text { ADC } 1000 \\
\text { Min-Max/Mean } \pm \text { SD/Median } \\
\left(\mathrm{X} 10^{-5} \mathrm{~mm}^{2} / \mathrm{s}\right)\end{array}$ & $\mathrm{p}$ & $\begin{array}{c}\text { ADC } 1500 \\
\text { Min-Max/Mean } \pm \text { SD/Median } \\
\left(\mathrm{X} 10^{-5} \mathrm{~mm}^{2} / \mathrm{s}\right)\end{array}$ & $\mathrm{p}$ \\
\hline \multicolumn{6}{|l|}{$\begin{array}{l}\text { Axillary } \\
\text { Lymph Node } \\
\text { Metastasis }\end{array}$} \\
\hline Negative (-) & $21(47.7 \%)$ & $0,58-1,90 / 0,99 \pm 0,27 / 1,00$ & ${ }^{\mathrm{a}} 0,017^{*}$ & $0,51-1,60 / 0,83 \pm 0,22 / 0,81$ & ${ }^{\mathrm{a}} 0,019 *$ \\
\hline $\begin{array}{l}1-3 \text { positive } \\
\text { node }(+)\end{array}$ & $10(22.7 \%)$ & $0,89-1,30 / 1,04 \pm 0,14 / 1,00$ & $\mathrm{a} 0,017 *$ & $0,68-1,00 / 0,87 \pm 0,11 / 0,87$ & a $0,019 *$ \\
\hline $\begin{array}{l}\text { 4-9 positive } \\
\text { node }(+)\end{array}$ & $9(20.5 \%)$ & $0,70-1,00 / 0,86 \pm 0,10 / 0,82$ & ${ }^{\mathrm{a}} 0,017^{*}$ & $0,62-0,88 / 0,72 \pm 0,10 / 0,72$ & ${ }^{\mathrm{a}} 0,019 *$ \\
\hline $\begin{array}{l}>9 \text { positive } \\
\text { node }(+)\end{array}$ & $4(9.1 \%)$ & $0,80-0,90 / 0,84 \pm 0,05 / 0,83$ & ${ }^{\mathrm{a}} 0,017 *$ & $0,59-0,75 / 0,68 \pm 0,07 / 0,69$ & ${ }^{\mathrm{a}} 0,019 *$ \\
\hline \multicolumn{6}{|l|}{$\begin{array}{l}\text { Histologic } \\
\text { Grade }\end{array}$} \\
\hline Grade 1 & $7(15.9 \%)$ & 1,00 & ${ }^{\mathrm{a}} 0,348$ & 0,83 & $\mathrm{a} 0,442$ \\
\hline Grade 2 & $13(29.5 \%)$ & 0,90 & a0,348 & 0,75 & a 0,442 \\
\hline Grade 3 & $24(54.6 \%)$ & 0,95 & ${ }^{\mathrm{a}} 0,348$ & 0,81 & $\mathrm{a} 0,442$ \\
\hline \multicolumn{6}{|l|}{$\begin{array}{l}\text { Nuclear } \\
\text { Grade }\end{array}$} \\
\hline Grade 1 & $3(6.8 \%)$ & 1,10 & a 0,174 & 0,91 & ${ }^{\mathrm{a}} 0,370$ \\
\hline Grade 2 & $20(45.5 \%)$ & 0,90 & ${ }^{\mathrm{a}} 0,174$ & 0,78 & a 0,370 \\
\hline Grade 3 & $24(47.7 \%)$ & 0,93 & a 0,174 & 0,82 & $\mathrm{a} 0,370$ \\
\hline \multicolumn{6}{|l|}{$\begin{array}{l}\text { Lymphovasc } \\
\text { ular invasion }\end{array}$} \\
\hline$(+)$ & $21(47.7 \%)$ & 099 & b0,868 & 0,81 & ${ }^{\mathrm{b}} 0,814$ \\
\hline$(-)$ & $23(52.3 \%)$ & 0,90 & b0,868 & 0,80 & ${ }^{\mathrm{b}} 0,814$ \\
\hline \multicolumn{6}{|l|}{$\begin{array}{l}\text { Esrogen } \\
\text { Receptor (ER) }\end{array}$} \\
\hline$(+)$ & $39(88.6 \%)$ & 0,93 & ${ }^{\mathrm{b}} 0,456$ & 0,79 & ${ }^{b} 0,365$ \\
\hline$(-)$ & $5(11.4 \%)$ & 0,90 & b 0,456 & 0,82 & ${ }^{b} 0,365$ \\
\hline \multicolumn{6}{|l|}{$\begin{array}{l}\text { Progesterone } \\
\text { Receptor (PR) }\end{array}$} \\
\hline$(+)$ & $30(68.2 \%)$ & 0,90 & b 0,275 & 0,78 & b0,512 \\
\hline$(-)$ & $14(31.8 \%)$ & 1,00 & ${ }^{b} 0,275$ & 0,82 & b 0,512 \\
\hline \multicolumn{6}{|l|}{$\begin{array}{l}\text { C-erbB-2 } \\
\text { Protein }\end{array}$} \\
\hline 0 & $28(63.7 \%)$ & 0,98 & ${ }^{\mathrm{a}} 0,710$ & 0,80 & ${ }^{\mathrm{a}} 0,291$ \\
\hline $1+$ & $4(9.1 \%)$ & 1,00 & ${ }^{\mathrm{a}} 0,710$ & 0,85 & a 0,291 \\
\hline $2+$ & $2(4.5 \%)$ & 0,91 & ${ }^{\mathrm{a}} 0,710$ & 0,63 & a0,291 \\
\hline $3+$ & $10(22.7 \%)$ & 0,90 & ${ }^{\mathrm{a}} 0,710$ & 0,80 & ${ }^{\mathrm{a}} 0,291$ \\
\hline
\end{tabular}

a Kruskal-Wallis Test ${ }^{\mathrm{b}}$ Mann-Whitney U Test ${ }^{*} \mathrm{p}<0,05$ 